\title{
Genetic associations between myasthenia gravis and the HL-A system
}

\author{
RITVA PIRSKANEN \\ From the Department of Neurology, University Central Hospital, Helsinki, Finland
}

SYNOPSIS HL-A antigens were determined in 159 myasthenic patients, 112 of whom were females and 47 males. Fifty-seven patients were thymectomized. The relationship between 23 different HL-A antigens and myasthenia gravis (MG) with reference to sex, age at onset, clinical course of MG, thymus histology, and auxiliary diseases of the patients, as well as the significance of these antigens to 245 relatives of myasthenics, were analysed. The frequencies of HL-A1 and HL-A8 were highly significantly higher in myasthenic patients than in normal Finnish controls. The increase of HL-A1 is secondary and due to a strong linkage disequilibrium between HL-A8 and HL-A1. HL-A8 appeared most often in females with onset of MG before the age of 35 years, and inpatients with thymus hyperplasia. No significant HL-A deviations were found in males or in females with later onset of disease. In seven thymoma patients the occurrence of W10 antigen was almost significantly increased.

In 1960 Simpson, Strauss et al., and Nastuk et al. (1959), independently suggested that myasthenia gravis (MG) might be some kind of autoimmune disease. This is well accepted today, even though the basic mechanism of the immunological dysfunction remains unresolved.

Many kinds of humoral autoantibodies have been found in myasthenic patients but their pathogenetic significance is still obscure. Several findings support the concept of alterations in the cell-mediated immunity, the well-known thymus pathology in about $80 \%$ of patients, the frequent presence of muscle lymphorrhages, the increased cytotoxicity of myasthenic lymphocytes both in vivo (Namba et al., 1969a, b) and in vitro (Armstrong et al., 1973), and the migration inhibition of myasthenic lymphocytes in the presence of muscle antigen (Alpert et al., 1972; Kott et al., 1973) and thymus antigen (Vejjajiva et al., 1974).

The increased occurrence of other autoimmune disorders in patients with MG has also been confirmed by many authors (Simpson, 1960; Oosterhuis et al., 1964; Oosterhuis and de Haas, 1968; Whittingham et al., 1970).

(Accepted 8 July 1975.)
The familial incidence of MG is higher than would be expected by chance: calculated by Namba et al. (1971), 3.4\% of 1875 patients are related as compared with approximately $0.01 \%$ in the population (Kurland and Alter, 1961). The pattern of inheritance is not clear and seems to be multifactorial.

We have sought evidence for the possible influence of inheritance by investigating one genetic polymorphism of tissue cells, the socalled human leucocyte antigens, or HL-A. The frequency of HL-A8 was found to be significantly increased in 38 unselected myasthenics, especially in women with onset of MG below the age of 30 years (Pirskanen et al., 1972). This finding has been confirmed by many others (Behan et al., 1973; Säfwenberg et al., 1973; Dick et al., 1974; Feltkamp et al., 1974; Fritze et al., 1974). Fritze et al. (1974) found in addition that HL-A3 was significantly increased in male patients and was also linked to thymoma. Feltkamp et al. (1974) did not confirm these findings but observed HL-A2 to be increased in patients with thymoma or with late onset of the disease. Both teams reported that HL-A8 was significantly increased in females with earlier 
TABLE 1

CLINICAL COURSE AND SEX OF 159 MYASTHENIC PATIENTS

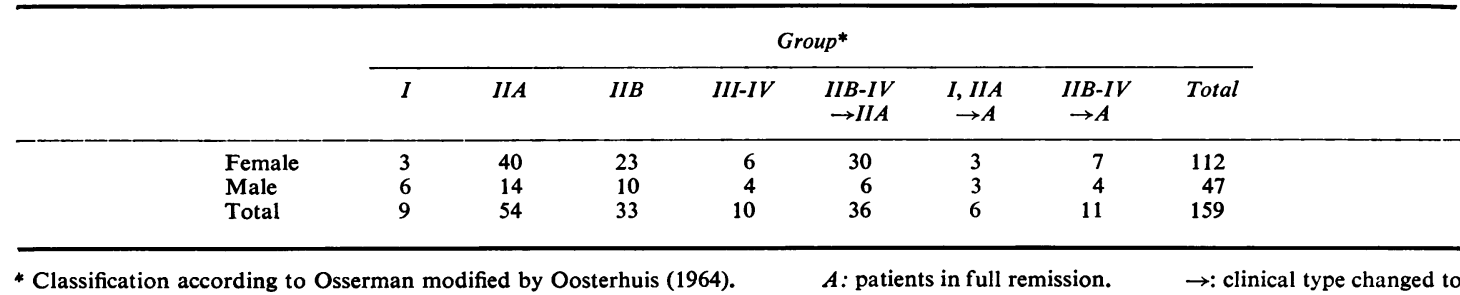

onset of MG than the age of 30 years or with hyperplastic thymus. In addition, they both showed that HL-A7 was more common in males.

The overall findings concerning HL-A antigens in myasthenia gravis seem to be somewhat controversial.

The purpose of this communication is to analyse further, with adequate statistical methods, the relationship between different HL-A antigens and myasthenia gravis with reference to the age at onset, sex, clinical form of MG, thymus histology, and associated diseases of patients. The haplotype and gene frequencies of different HL-A antigens are determined. The significance of the HL-A8 antigen to family members of myasthenics will be discussed.

\section{METHODS}

PATIENTS On 1 November 1974, there were in Finland 235 myasthenics per 4,560,000 inhabitants, $169(72 \%)$ of whom were females and $66(28 \%)$ males. The number of familial cases was 12 per 235 , or $5.1 \%$. During the clinical follow-up examination from January 1972 to August 1974, the HL-A antigens were determined in $159(68 \%)$ myasthenics from various parts of Finland. Of these $112(70.4 \%)$ were women and $47(29.6 \%)$ men, the sex distribution thus being the same as in the entire group of patients. The sex distribution and the clinical forms of MG grouped according to Osserman modified by Oosterhuis (Oosterhuis, 1964) are shown in Table 1. Thymectomy was performed on 57 of the 159 myasthenics, 45 females and 12 males. Thymoma was found in five females and two males $(12.5 \%), 38$ patients ( 32 females and six males-or $66.1 \%$ ) had lymphoid hyperplasia and two females and four males $(10.7 \%)$ had a normal thymus histology. In six patients the histological picture of the removed thymus had not been recorded. The sex distribution
TABLE 2

THYMUS HISTOLOGY AND SEX OF 57 THYMECTOMIZED MYASTHENICS

\begin{tabular}{lccccc}
\hline & $\begin{array}{c}\text { Hyper- } \\
\text { plasia }\end{array}$ & Thymoma & Normal & Unknown & Total \\
\hline Female & 32 & 5 & 2 & 6 & 45 \\
Male & 6 & 2 & 4 & 0 & 12 \\
Total & 38 & 7 & 6 & 6 & 57 \\
\hline
\end{tabular}

and the histological findings in the thymus gland of 57 thymectomized patients are shown in Table 2.

The HL-A antigens of 245 relatives of 106 myasthenic patients were determined. The haplo-zo types of 93 myasthenic patients were thus ascertained. The diseases of these relatives in relation to HL-A antigens were also analysed.

The blood samples were collected during the clinical follow-up examination. The lymphocytes were separated immediately and the tissue typing was performed by Dr Anja Tiilikainen at the Department of Serology and Bacteriology, University of Helsinki. The investigation included the following HL-A antigens: first (SD I) or LA locus: HL-A1, 2, $3,9,10,11,28$, W19 (W29, 30, 31, 32 were all called W19 because they could not be separately identified throughout the work); the identified second (SD II) or FOUR locus antigens included HL-A5, 7, 8, 12, $13,14,17,27$, W5, W10, W15, W16, W18, W21, W22 throughout.

The statistical significance of deviations from the controls was based on calculations of $\chi^{2}$ values. Because of a possibility of overestimation of the association between an antigen and the disease, the resultant $P$-values were multiplied by 23 , the number of specificities being tested ("correctedP-values'). P-value $<0.001$ will be described as 'highly significant', $<0.01$ as 'significant', and $<0.05$ as 'almost significant'. The corresponding gene frequencies were calculated in two ways (see 
Table 7). $P_{1}$ states the observed gene frequency calculated directly from the haplotyped patients. $\mathrm{P}_{2}$ is the gene frequency estimated from all the myasthenics by the formula: $P=1-\sqrt{1-A}$; where $A$ is the phenotype frequency of the antigen.

When evaluating the significance of deviations of HL-A haplotype frequencies from controls the so called delta $(\Delta)$ values are of importance because they provide the estimate of a genetic association between certain SDI and SDII antigens. The delta value, or linkage disequilibrium parameter, is calculated by the formula: $\Delta=f_{i j}-g_{i} \times g_{j}$; where $f_{i j}$ is the frequency of joint occurrence of the antigens $i$ and $j$ on the same haplotype and $g_{1}$ and $g_{j}$ are the gene frequencies (Bodmer and Payne, 1965). In other words, $f_{i j}$ is the observed frequency of a given HL-A haplotype and $g_{1} \times g_{j}$ gives the expected value of that haplotype frequency if all the antigens were linked together by chance.

\section{RESULTS}

In Table 3 the HL-A phenotype frequencies of 159 myasthenics are compared with those of 326 normal Finnish controls (Tiilikainen et al.,1972). The corrected P-values show that the increases of HL-A1 $(35.2 \%)$ in the SD I and of HL-A8 $(47.8 \%)$ in the SD II segregation group are highly significant.

Among the SD II antigens HL-A7 (16.7\%) is almost significantly and W15 $(11.3 \%)$ highly significantly decreased.

In the random Finnish population HL-A7 is the most common and W15 the second most common antigen of the SD II group. The HL-A8 frequency in myasthenics is 2.73 -fold as compared with controls. If non-HL-A8 antigens were

TABLE 3

HL-A PHENOTYPES IN 159 MYASTHENICS AND 326 NORMAL FINNISH CONTROLS

\begin{tabular}{|c|c|c|c|c|c|}
\hline \multicolumn{2}{|r|}{ Antigen } & \multicolumn{3}{|c|}{159 myasthenic patients } & \multirow{3}{*}{$\begin{array}{c}326 \\
\text { normal } \\
\text { controls } \\
\text { phenotype } \\
\text { frequency } \\
(\%)\end{array}$} \\
\hline & & \multicolumn{2}{|c|}{ Number of antigens } & \multirow{2}{*}{$\begin{array}{l}\text { Phenotype } \\
\text { frequency } \\
(\%)\end{array}$} & \\
\hline & & Observed & Expected & & \\
\hline \multicolumn{6}{|c|}{$\begin{array}{l}\text { SD I : First segr. } \\
\text { group (LA) }\end{array}$} \\
\hline \multirow[t]{7}{*}{ HL- } & 1 & 56 & 26.8 & $35.2^{*}$ & 16.9 \\
\hline & 2 & 77 & 87.3 & 48.4 & 55.2 \\
\hline & 3 & 53 & 66.3 & $33.3^{(3)}$ & 42.0 \\
\hline & 9 & 30 & 28.8 & 18.9 & 18.4 \\
\hline & 10 & 5 & 15.1 & $3.1^{(2)}$ & 9.8 \\
\hline & 11 & 14 & 16.1 & 8.8 & 10.4 \\
\hline & 28 & 20 & 19.0 & 12.6 & 12.0 \\
\hline W- & 19 & 22 & 24.4 & 13.8 & 15.6 \\
\hline \multicolumn{6}{|c|}{$\begin{array}{l}\text { SD II: second segr. } \\
\text { group (FOUR) }\end{array}$} \\
\hline \multirow[t]{8}{*}{ HL } & 5 & 18 & 20.0 & 11.3 & 12.6 \\
\hline & 7 & 26 & 45.9 & $16.4 \div(1)$ & 29.1 \\
\hline & 8 & 76 & 27.8 & $47.8^{*}$ & 17.5 \\
\hline & 12 & 22 & 22.9 & 13.8 & 14.7 \\
\hline & 13 & 6 & 12.2 & 3.8 & 7.7 \\
\hline & 14 & 2 & 0.0 & 1.3 & - \\
\hline & 17 & 7 & 5.9 & 4.4 & 3.7 \\
\hline & 27 & 10 & 22.0 & $6.3^{(2)}$ & 14.1 \\
\hline \multirow{2}{*}{ W- } & 5 & 35 & 29.3 & 22.1 & 18.7 \\
\hline & 10 & 35 & 24.0 & $22.1^{(3)}$ & 15.3 \\
\hline \multirow{2}{*}{ - } & 15 & 18 & 41.0 & $11.3 *$ & 25.8 \\
\hline & 16 & 18 & 19.0 & 11.3 & 12.0 \\
\hline \multirow{2}{*}{ - } & 18 & 13 & 7.3 & $8.2^{(3)}$ & 4.9 \\
\hline & 21 & - & 0.0 & - & - \\
\hline - & 22 & 6 & 11.2 & 3.8 & 7.1 \\
\hline
\end{tabular}

P-values:

$\begin{aligned} & \text { Uncorrected } \\ \mathrm{P}<0.001 & \text { (1) } \\ 0.001<\mathrm{P}<0.01 & \text { (2) } \\ 0.01<\mathrm{P}<0.05 & \text { (3) }\end{aligned}$

Corrected

multiplied by 23

* Highly significant

+ Significant

$\ddagger$ Almost significant 
TABLE 4

HL-A PHENOTYPES (PER CENT) IN 159 MYASTHENICS ACCORDING TO AGE AT ONSET AND SEX

\begin{tabular}{|c|c|c|c|c|c|}
\hline \multirow[t]{2}{*}{ Antigen } & \multicolumn{2}{|c|}{112 female myasthenics } & \multicolumn{2}{|c|}{47 male myasthenics } & \multirow{2}{*}{$\begin{array}{l}326 \text { normal } \\
\text { controls }\end{array}$} \\
\hline & $\begin{array}{c}\text { Before age } \\
35 \mathrm{yr} \\
\text { (75 patients) }\end{array}$ & $\begin{array}{c}\text { After age } \\
35 \mathrm{yr} \\
\text { (37 patients) }\end{array}$ & $\begin{array}{c}\text { Before age } \\
35 \mathrm{yr} \\
(22 \text { patients) }\end{array}$ & $\begin{array}{c}\text { After age } \\
35 y r \\
\text { (25 patients) }\end{array}$ & \\
\hline HL-A 1 & $48.0^{*}$ & 28.9 & 27.3 & 12.5 & 16.9 \\
\hline 2 & 42.7 & 36.8 & 59.1 & 75.0 & 55.2 \\
\hline 3 & 29.3 & 31.6 & 36.4 & 45.8 & 42.0 \\
\hline 9 & 14.7 & 23.7 & 36.4 & 8.3 & 18.4 \\
\hline 10 & 2.7 & - & 4.5 & 8.3 & 9.8 \\
\hline 11 & 6.7 & 15.8 & - & 12.5 & 10.4 \\
\hline 28 & 16.0 & 10.5 & 4.5 & 12.5 & 12.0 \\
\hline W-19 & 14.7 & 15.8 & 4.5 & 16.7 & 15.6 \\
\hline HL-A 5 & 8.0 & 7.9 & 22.7 & 16.7 & 12.6 \\
\hline 7 & 16.0 & 18.4 & 13.6 & 16.7 & 29.1 \\
\hline 8 & $72.0^{*}$ & 26.3 & 40.9 & 12.5 & 17.5 \\
\hline 12 & 9.3 & 13.2 & 18.2 & 25.0 & 14.7 \\
\hline 13 & 2.7 & 7.9 & - & 4.2 & 7.7 \\
\hline 14 & 1.3 & 2.6 & - & - & - \\
\hline 17 & 1.3 & 10.5 & 9.1 & - & 3.7 \\
\hline 27 & 10.7 & 2.6 & - & 4.2 & 14.1 \\
\hline W- 5 & 24.0 & 15.8 & 13.6 & 33.3 & 18.7 \\
\hline 10 & 16.0 & 31.6 & 27.3 & 20.8 & 15.3 \\
\hline 15 & $9.3 \ddagger$ & 18.4 & 13.6 & 8.3 & 25.8 \\
\hline 16 & $9.3^{+}$ & 10.5 & 18.2 & 12.5 & 12.0 \\
\hline 18 & 8.0 & 7.9 & 9.1 & 8.3 & 4.9 \\
\hline 21 & - & - & - & 16.7 & - \\
\hline 22 & - & 2.6 & 4.5 & - & 7.1 \\
\hline
\end{tabular}

*, $¥:$ see footnotes to Table 3 .

present in the same proportions as in the random population, the expected frequencies of HL-A7 and W15 would be $18.4 \%$ and $16.4 \%$, respectively. These figures differ from the observed only by 2 and $5 \%$ units. The differences are not statistically significant and the decreases of HL-A7 and W15 seem to be secondary and caused by the increase of HL-A8. Deviations in the uncorrected $\mathrm{P}$-values are also given in the table.

Table 4 presents the phenotype frequencies in the different age and sex groups. We also determined the frequencies in the group contracting the disease before the age of 16 years, but these did not differ from those of the group with onset at below the age of 35 years. The age of 35 years was selected for the division of patients according to age because of all groupings at five year intervals this revealed the best discrimination for HL-A8 frequencies.

The only significantly increased frequencies are those of HL-A1 and 8 in the younger female group. The decrease of W15 in the same group is secondary and due to the increase of HL-A8.

In males and in the older age group of females no significant deviations from normal controls were found when only the corrected P-values are considered.

Table 5 compares the occurrence of HL-A antigens in the different clinical groups. The figures are given in numbers of cases because of the small size of some patient groups.

In the occular group (I) there are no significant deviations from the controls. In the milder MG group (IIA) HL-A 8 is found in $41.4 \%$; in the more severe form of the disease (IIB-IV) in $37.2 \%$; and in patients who improved with time (IIB-IV changes to IIA or to A) (the majority after thymectomy) in $72.3 \%$. All these increases are significant. In the IIB-IV group the decrease of HL-A7 is almost significant.

Table 6 presents the occurrence of HL-A antigens of the thymectomized patients, grouped according to the microscopic picture of the thymus gland. HL-A1 $(55.3 \%)$ and HL-A8 $(73.7 \%)$ were highly significantly increased in the hyperplasia group and W10 $(57.1 \%)$ almost significantly increased in the thymoma group.

The haplotype and exact gene frequencies $\left(p_{1}\right)$ of the randomly haplotyped 93 patients are given in Table 7a. The estimated gene frequencies 
TABLE 5

HL-A PHENOTYPES (NUMBER OF CASES) IN 159 MYASTHENICS WITH DIFFERENT CLINICAL COURSES

\begin{tabular}{|c|c|c|c|c|}
\hline \multirow[t]{2}{*}{ Antigen } & \multicolumn{4}{|c|}{ Groups } \\
\hline & $\begin{array}{c}I, I \rightarrow A \\
\text { (11 patients) }\end{array}$ & $\begin{array}{l}I I A, I I A \rightarrow A \\
\text { (58 patients) }\end{array}$ & $\begin{array}{r}I I B, I I I, I V \\
\text { (43 patients) }\end{array}$ & $\begin{array}{l}I I B-I V \rightarrow I I A \text { or } A \\
\quad(47 \text { patients })\end{array}$ \\
\hline HL-A 1 & 5 & $19(32.7 \%) \ddagger$ & 13 & $22(46.8 \%)^{*}$ \\
\hline 2 & 6 & 28 & 21 & 22 \\
\hline 3 & 5 & 19 & 13 & 16 \\
\hline 9 & 3 & 10 & 10 & 7 \\
\hline 10 & 1 & 1 & 2 & 1 \\
\hline 11 & - & 9 & 4 & 1 \\
\hline 28 & 1 & 7 & 6 & 6 \\
\hline W-19 & - & 7 & 6 & 9 \\
\hline HL-A 5 & 2 & 6 & 9 & 1 \\
\hline 7 & 2 & 12 & $3(7.0 \%) \ddagger$ & 9 \\
\hline 8 & 2 & $24\left(41.4^{\circ} \%\right)^{*}$ & $16(37.2 \%) \dagger$ & $34(72.3 \%)^{*}$ \\
\hline 12 & 1 & 14 & 4 & 4 \\
\hline 13 & 1 & 2 & 2 & 1 \\
\hline 14 & - & 1 & 1 & 一 \\
\hline 17 & - & 3 & 2 & 2 \\
\hline 27 & - & 3 & 2 & 5 \\
\hline W- 5 & 4 & 10 & 8 & 13 \\
\hline-10 & 3 & 12 & 9 & 11 \\
\hline-15 & 1 & 7 & 5 & 15 \\
\hline-16 & 2 & 6 & 8 & 2 \\
\hline-18 & 1 & 4 & 4 & 4 \\
\hline-21 & - & - & - & - \\
\hline-22 & 1 & 2 & 3 & - \\
\hline
\end{tabular}

$*, \dagger, \ddagger$ : see footno:es to Table $3 . \quad \rightarrow$ : clinical type changed to.

TABLE 6

HL-A PHENOTYPES (NUMBER OF CASES) AND THYMUS HISTOLOGY IN 57 THYMECTOMIZED PATIENTS

\begin{tabular}{|c|c|c|c|c|}
\hline Antigen & $\begin{array}{l}\text { Normal } \\
\text { histology }\end{array}$ & $\begin{array}{c}\text { Hyperplastic } \\
\text { thymus }\end{array}$ & Thymoma & $\begin{array}{l}\text { Unknown } \\
\text { histology }\end{array}$ \\
\hline HL-A 1 & 2 & $21(55.3 \%)^{*}$ & 1 & 3 \\
\hline 2 & 5 & 12 & 5 & 4 \\
\hline 3 & 2 & 10 & 4 & - \\
\hline 9 & - & 5 & 2 & 1 \\
\hline 10 & - & 1 & - & - \\
\hline 11 & 1 & 2 & - & - \\
\hline 28 & - & 6 & - & 1 \\
\hline W-19 & - & 9 & 1 & - \\
\hline HL-A 5 & 2 & 2 & 1 & - \\
\hline 7 & 1 & 5 & 2 & - \\
\hline 8 & 3 & $28(73.7 \%)^{*}$ & 1 & 6 \\
\hline 12 & 3 & 4 & - & 1 \\
\hline 13 & - & 1 & - & - \\
\hline 14 & - & 1 & - & - \\
\hline 17 & - & 1 & - & - \\
\hline 27 & - & 2 & 1 & - \\
\hline$w-5$ & 3 & 6 & 2 & - \\
\hline 10 & 1 & 10 & $4(57.1 \%) \ddagger$ & - \\
\hline 15 & - & 2 & 2 & 2 \\
\hline 16 & - & 3 & - & 1 \\
\hline 18 & - & 4 & - & - \\
\hline 21 & - & - & - & - \\
\hline 22 & - & - & - & - \\
\hline $\begin{array}{c}\text { Total number } \\
\text { of patients }\end{array}$ & 6 & 38 & 7 & 6 \\
\hline
\end{tabular}

*, $\ddagger$ : see footnotes to Table 3 . 

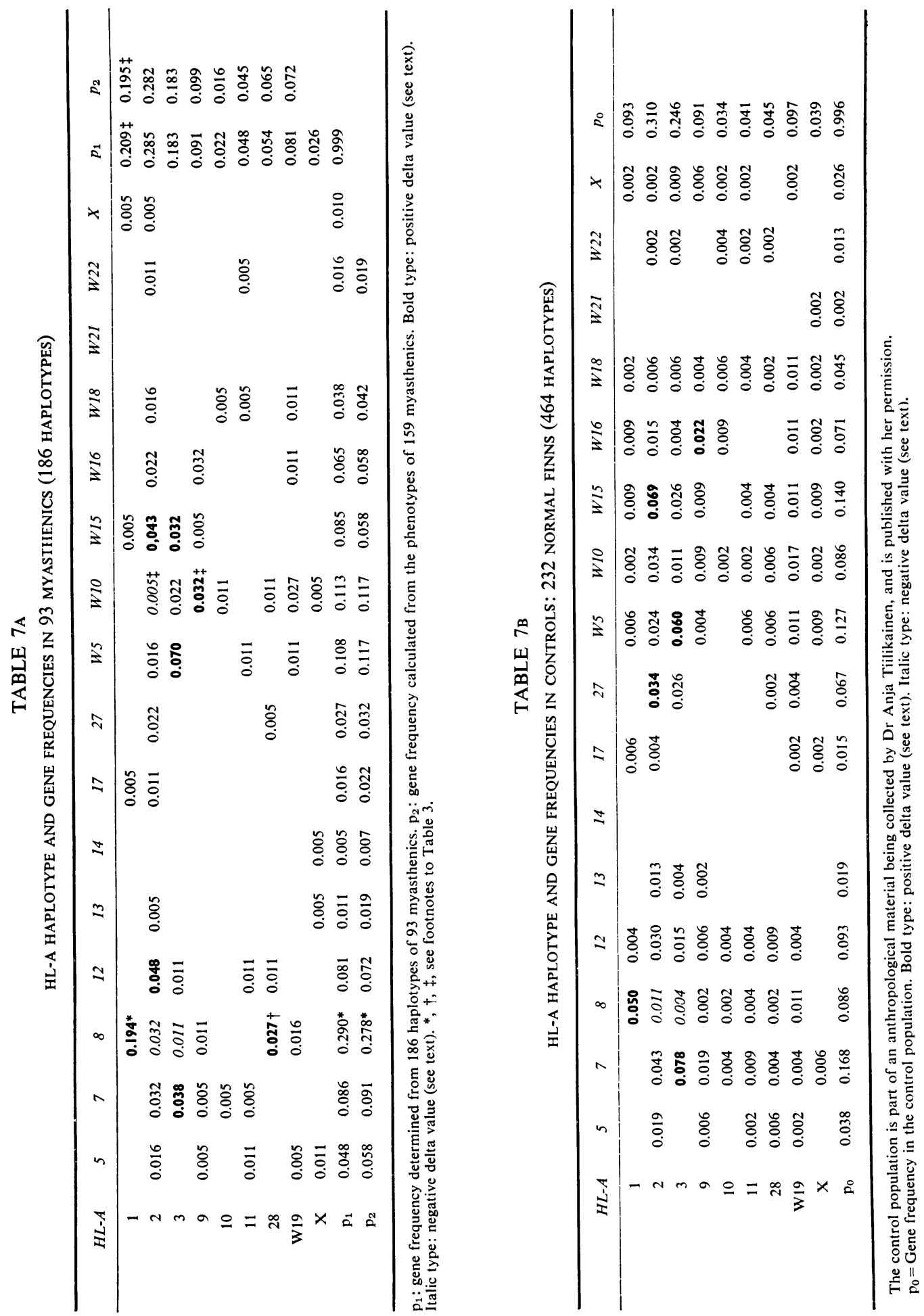
TABLE 8

INHERITANCE OF HL-A8 BY FEMALE AND MALE MYASTHENICS

\begin{tabular}{lccc}
\hline \multicolumn{1}{c}{ Patients } & $\begin{array}{c}\text { From } \\
\text { father }\end{array}$ & $\begin{array}{c}\text { From } \\
\text { mother }\end{array}$ & Total \\
\hline Female & 16 & 11 & 27 \\
Male & 3 & 0 & 3 \\
Total & 19 & 11 & 30 \\
& $63.3 \%$ & $36.6 \%$ & \\
\hline
\end{tabular}

A comparison of the frequencies in myasthenics and controls (Table 7b) shows an increase of haplotype 1.8 (highly significant), 28.8 (significant), and 9.W10 (almost significant), and an almost significant decrease of haplotype 2.W10 in MG patients. When only corrected $P$ values are taken into account, the increase of the gene determining HL-A1 in myasthenics is almost significant and that one determining HLA8 highly significant. If uncorrected $\mathrm{P}$-values are

TABLE 9

FAMILIAL CASES OF MYASTHENTA AND THEIR HL-A TYPES

\begin{tabular}{|c|c|c|c|}
\hline Relationship & $H L-A$ type & Comments & $\begin{array}{c}\text { Age at onset } \\
(y r)\end{array}$ \\
\hline Mother & $1,8 / 3 \mathrm{~W} 5$ & Thymus radiated & 21 \\
\hline Son & $1,8 / 2, \mathrm{~W} 16$ & Mild myasthenia & 7 \\
\hline First cousin $\mathbf{A}$ & $1,8 / 11, \mathrm{~W} 5$ & $\begin{array}{l}\text { Systemic lupus } \\
\text { erythematosus }\end{array}$ & 23 \\
\hline First cousin $\mathbf{B}$ & $1,8 / 9, \mathrm{~W} 10$ & $\begin{array}{l}\text { Normal thymus } \\
\text { histology }\end{array}$ & 12 \\
\hline First cousin $\mathrm{C}$ & $2,27 / 28,5$ & Very mild myasthenia & 15 \\
\hline Second cousin D & $1,8 / 3$, W5 & Hyperplastic thymus & 12 \\
\hline Sister A & $28,8 / W 19, W 5$ & Hyperplastic thymus & 19 \\
\hline Sister B & $9,7 / \mathrm{W} 19, \mathrm{~W} 5$ & Very mild myasthenia & 16 \\
\hline Sister & W19,8/W19,W16 & Hyperplastic thymus & 19 \\
\hline Brother & W'19,8/W19,W16 & Very mild myasthenia & 22 \\
\hline
\end{tabular}

TABLE 10

HL-A8 IN 245 RELATIVES OF 106 MYASTHENICS

\begin{tabular}{lccc}
\hline & \multicolumn{2}{c}{245 relatives } & \\
\cline { 2 - 3 } & Healthy & Unhealthy & Total \\
\hline HL-A8+ & 50 & 52 & 102 \\
HL-A8 - & $49.0 \%$ & $51.0 \%$ & $41.6 \%$ \\
& $78 \%$ & 65 & 143 \\
Total & $54.6 \%$ & $45.4 \%$ & $58.4 \%$ \\
\hline & 128 & 117 & 245 \\
\hline
\end{tabular}

$\left(\mathrm{p}_{2}\right)$ of the whole myasthenic series are also presented. The exact and estimated gene frequencies $\left(\mathrm{p}_{1}\right.$ and $\left.\mathrm{p}_{2}\right)$ do not differ significantly from each other, which confirms that the haplotyping is performed randomly.

In this Table the bold type indicates positive delta values exceeding 0.015 -for example, the observed haplotype frequency is higher than the expected frequencycalculated from corresponding gene frequencies (Bodmer, 1972). The italic type indicates negative delta values (correspondingly calculated). also taken into account the frequencies of HL-A7 and HL-A27 are significantly and almost significantly decreased. Parental HL-A determination resolves whether HL-A8 is inherited from mother or father in 30 myasthenic patients (Table 8). It is received from the mother in 11 and from the father in 19 patients. The difference is statistically almost significant $\left(\chi^{2} 4.27\right.$ or $\mathbf{P}<0.05)$.

HL-A antigens were examined in 10 familial myasthenic patients and are presented in Table 9. One mother and son, three first cousins and one second cousin, two sisters, and a sister and a brother belonging to four different families are included. Not even in them is myasthenia absolutely associated with HL-A8. The two patients lacking HL-A 8 have very mild myasthenia symptoms. It is worth mentioning that in these cousins the $\mathrm{LD}^{1}$ antigen commonly associated with HL-A8 and with myasthenia is not detected

1 'Lymphocyte defined' antigens are controlled by a further locus in the MHC region. 
(Kaakinen et al., in press). The increased frequency of HL-A8 both in myasthenia gravis and in certain other autoimmune/endocrine disorders, confirmed by many authors, raises the question whether this antigen or the gene coding for it might be associated with an autoimmune or endocrine disorder present, either in myasthenics or in their relatives.

The HL-A antigens of 202 first degree relatives (parents, children, siblings) and of 43 second degree relatives of 106 myasthenic patients in 102 different families were determined. The average number of relatives in one family was 2.4 (range one to nine) in addition to the patient.

Of these 245 relatives, $128(52.2 \%)$ are totally healthy, and $50(49.0 \%)$ of them have HL-A8 determinant. Concerning various disease groups, it can be mentioned that seven of 245 relatives $(2.9 \%)$ have some kind of autoimmune disease -for example, rheumatoid arthritis, systemic lupus erythematosus, glomerulonephritis-and two of them have HL-A8; $16(6.5 \%)$ have thyroid gland disorders (including non-toxic goitre), of whom six $(37.5 \%)$ are HL-A $8+$; $12(4.9 \%)$ have some other endocrinopathy-for example, diabetes mellitus-of whom six $(50 \%)$ are HL-A $8+$; and $18(7.4 \%)$ of these 245 relatives have some kind of atopic tendency-for example, bronchial asthma, hay fever, or allergic eczema-of whom six $(33.3 \%)$ have HL-A8.
The incidence of autoimmune, allergic, or endocrine disorders is even lower in HL-A8 positive than HL-A8 negative relatives. Table 10 summarizes the frequency of HL-A8 in these 245 healthy and unhealthy relatives of myasthenics.

With regard to segregation of any of these diseases with HL-A antigens, these family pedigree studies turned out to be unproductive, even though in some families some atopic tendency seems to segregate with HL-A8.

Table 11 presents certain associated diseases in 159 myasthenics and their relation to HL-A8. The significances are calculated by comparing the observed frequency of HL-A8 in a group of $n$ myasthenics having a given additional disorder with the frequency of HL-A8 in the (159-n) myasthenics. The frequency of rheumatoid arthritis (criteria according to American Rheumatoid Association) was $3.8 \%$, systemic lupus erythematosus $1.9 \%$, thyroid hormone disorders $9.4 \%$, and 'neurovegetative' symptoms-for example, general asthenia, acrocyanosis, cardiace arrhythmias, abnormal sweating, and chill, etc. $23.9 \%$. These are all increased compared with a Finnish control population. The frequencies of HL-A8 in these patients do not differ from the frequencies in the myasthenics without the said disorders with the exception of patients witf 'neurovegetative' symptoms in whom HL-A8 is 'almost significantly' $(\mathrm{P}<0.05)$ increased. It is also interesting to find that HL-A8 is almost

TABLE 11

SOME ASSOCIATED DISORDERS OF 159 MYASTHENICS AND THE INCIDENCE OF HL-A8

\begin{tabular}{|c|c|c|c|c|}
\hline \multirow[t]{2}{*}{ Disorder } & \multicolumn{2}{|c|}{$\begin{array}{c}\text { Additional disorders in } 159 \\
\text { myasthenics }\end{array}$} & \multicolumn{2}{|c|}{ With $H L-A 8$} \\
\hline & (no.) & $(\%)$ & (no.) & $(\%)$ \\
\hline Rheumatoid arthritis (ARA criteria) & \multirow{11}{*}{$\begin{array}{l}19= \\
12.0 \%\end{array}$} & 3.8 & \multirow{6}{*}{$\left.\begin{array}{l}2 \\
1 \\
3 \\
1 \\
0 \\
0\end{array}\right\} 82.1 \%$} & \multirow{5}{*}{$\begin{array}{r}33.3 \\
33.3 \\
50.0 \\
100.0 \\
\end{array}$} \\
\hline Systemic lupus erythematosus & & 1.9 & & \\
\hline Arthritis NUD & & 3.8 & & \\
\hline Scleroderma & & 0.6 & & \\
\hline Glomerulonephritis chronic & & 0.6 & & \\
\hline Sjögren's syndrome & & 0.6 & & - \\
\hline Pemphigus & & 0.6 & 1) & 100.0 \\
\hline Atopia & & 8.8 & 10 & 71.4 \\
\hline Thyroid hormone disorder & & 9.4 & 7 & 46.7 \\
\hline Non-toxic goitre & & 11.3 & 8 & 44.4 \\
\hline $\begin{array}{l}\text { 'Vegetative' symptoms } \\
\text { (acrocyanosis, etc.) }\end{array}$ & & 23.9 & 25 & $65.8 \ddagger$ \\
\hline $\begin{array}{l}\text { Neurological symptoms } \\
\text { Some effect of menstrual cycle on }\end{array}$ & 35 & 22.0 & 12 & 34.3 \\
\hline $\begin{array}{l}\text { MG (102 females) } \\
\text { No additional disease }\end{array}$ & $\begin{array}{l}58 \\
32\end{array}$ & $\begin{array}{l}56.8 \\
20.1\end{array}$ & $\begin{array}{l}34 \\
21\end{array}$ & $\begin{array}{l}58.6 \\
65.6 \pm\end{array}$ \\
\hline
\end{tabular}

* $\ddagger$ : see footnotes to Table 3. 
significantly increased in myasthenics with no other illness. However, many of these associated disorders are too infrequent to justify conclusions concerning their association with HL-A8.

\section{DISCUSSION}

It is now well accepted that both immunogenicity of certain biological compounds and immune responsiveness are genetically controlled. Many other factors, of course, also have effects on the immune response.

Transplantation antigens, including HL-A antigens, are one group of genetically controlled immunogens. HL-A antigens are polypeptide structures mimicking immunoglobulins in the plasma membranes of all cells. They can be detected by serological methods and are thus also called SD (serologically defined) antigens. The genes coding for HL-A antigens are situated in autosome no. 6 in a region called Major Histocompatibility Complex (MHC) (Figure) and are in several loci, the best known of which

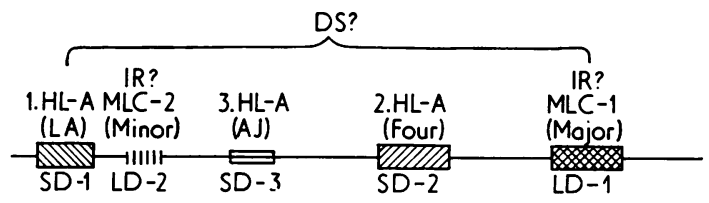

FIGURE Genetic map of the major histocompatibility complex (MHC) in man. SD-1 and SD-2-Genes for best-known HL-A antigens. LD-1-Genes for bestknown LD-antigens. IR-Immune response-genes. DS-Disease susceptibility genes.

are called LA (SD I) and FOUR (SD II). LA includes at least 14 and FOUR 16 alleles. An individual inherits a haplotype with one LA and one FOUR gene from each parent and may thus produce principally four different HL-A antigens in his cells. The inheritance is codominant. There is increasing evidence that the $\mathrm{MHC}$ region, at least near the FOUR locus, includes genes that affect disease susceptibility or resistance. Susceptibility to certain viruses and some diseases with alterations in the immunomechanism may be mentioned as candidates for a MHC-linked genetic control (Ceppellini and van Rood, 1974). The possible role of HL-A antigens in certain diseases (McDevitt and Bodmer, 1974) could be explained by molecular mimicry between these and microbial antigen, or HL-A might act as or interact with receptor sites on the cell surface for the attachment of microbes, or HL-A products might simply act as markers for closely linked genes in MHC that may be involved in the synthesis or control of cell surface structures, or otherwise influence the penetrance of a multigenic disease.

In this study, the only really significant deviation from normal controls is the increased frequency of the FOUR locus antigen, HL-A8. All other deviations seem to be secondary and due to the very marked association of HL-A8 with myasthenia gravis. Thus there is an increase of HL-A1 only in the haplotype 1.8 ; most other haplotypes with HL-A8 are also increased. Surprisingly, the haplotype $2 . \mathrm{W} 10$ is almost significantly decreased, while haplotype $9 . \mathrm{W} 10$ is almost significantly increased. HL-A8 is increased especially in female myasthenics with neurovegetative lability, or with onset of myasthenia below the age of 35 years, with thymus hyperplasia, or with the typical generalized clinical course.

In our patients, HL-A8 is inherited almost significantly $(P<0.05)$ more often from the father (19 subjects) than from the mother (11 subjects). This could be connected with the combined evidence by various authors showing that, in familial cases, myasthenia appears more often in father and child than in mother and child. The same inheritance was not found by Behan et al. (1973). In their study of eight cases HL-A8 was inherited four times each from father and from mother.

We did not find any significant increase of HL-A2 or 3 in thymoma patients, contrary to Feltkamp et al. (1974) and Fritze et al. (1974). Instead, we found W10 to be almost significantly increased in thymoma patients, but our thymoma material is too small for definite conclusions. In our study HL-A8 seems to be of no importance to 245 relatives of 106 myasthenics in respect of an increased risk of an autoimmune or endocrine disorder. Even in familial cases, HL-A8 is not always found, indicating that it may be only one 
of the many factors that are required for the outbreak of myasthenia gravis or of another immunological disorder.

Myasthenics with no other additional symptoms have a high incidence of HL-A8 $(65.6 \% \mathrm{HL}-\mathrm{A} 8+)$. We can assume that this is the 'basic figure' indicating the effect of HL-A8 on the penetrance of myasthenia. Both the socalled collagen diseases and thyroid disorders occur in myasthenic patients more often than in the whole population. In this study the incidence of HL-A8 in these patients is a little lower than the 'basic figure'. Perhaps these disorders facilitate penetrance of myasthenia gravis. The joint influence of all these disease susceptibility factors may render the presence of the HL-A8associated susceptibility factors superfluous. In any case, the number of examples of each disorder in the present study is too small to justify conclusions of their effect on the frequency of HL-A8. It is interesting to note that myasthenics with different neurovegetative symptoms (most often acrocyanosis and general asthenia) have HL-A8 more often than myasthenics without those symptoms.

HL-A 8 has been demonstrated in other studies to be associated with several other diseases featuring lymphocytic infiltration of a target organ and/or the thymus: this is the case with chronic active autoimmune hepatitis (MacKay and Morris, 1972), dermatitis herpetiformis (Gebhard et al., 1973), Graves' disease (Grumet et al., 1973), idiopathic Addison's disease (Platz et al., 1974), some forms of systemic lupus erythematosus (Grumet et al., 1971), juvenile diabetes (Nerup et al., 1974), coeliac disease (Stokes et al., 1972), and perhaps with childhood asthma (Thorsby et al., 1971). HL-A8 or an associated immune response (IR) gene might thus be one of the factors affecting endocrine autoimmunity. We have also looked for some specific LD (IR ?) gene with a strong positive disequilibrium linkage with HL-A8 that would better explain the very marked association between myasthenia and HL-A8.

One specific LD gene (LD-8a) was found to be linked strongly to HL-A8 but only a little more often in myasthenics than in control persons. A specifically myasthenia-associated LD gene as determined by MLC technique was not found (Kaakinen et al., in press). Thus a possible myasthenia-susceptibility gene(s) may be situated closer to the FOUR locus than to the LD-1 locus. The clinical, serological, and familial overlap of certain autoimmune diseases suggests that they may have a common genetic base and that some extrinsic factor (possibly one causing somatic mutation in lymphoid stem cells) is needed to bring forth a particular autoimmune disease. In myasthenia gravis these mutated immunocytes or some product of theirs might then be directed against substances (for example, cholinacetylase?) in the synaptic area or against the neurotransmitter receptor site. This need not be a true antigen-antibody reaction. It is worth mentioning that HL-A8 is found in the plasma membrane of all cells, also of nerve and muscle cells, and that in MG morphological changes have been shown in the membranes of both these cells. HL-A8 may also represent a genetically determined weak point in either of these membranes.

Histocompatibility antigens have given neithe an aetiological nor a pathogenetic explanation but have added to the evidence for inherited $\overrightarrow{\mathcal{P}}$ susceptibility to myasthenia gravis. The exact relationship between them remains to beg clarified.

This investigation was supported by grants from Finnish Cultural Foundation (Suomen Kulttuurirahasto), Finnish Medical Foundation (Suomen Lääketieteen säätiö), and Paulo Foundation (Paulon säätiö). I would particularly like to thank Dr Anja Tiilikainen for her excellent advice and support during the course of the study.

\section{REFERENCES}

Alpert, L. J., Rule, A., Norio, M., Kott, E., Kornfield, P., and Osserman, K. E. (1972). Studies in myasthenia gravis: Cellular hypersensitivity to skeletal muscle. American Journal of Clinical Pathology, 58, 647-653.

Armstrong, R. M., Nowak, E. M., and Falk, R. E. (1973). Thymic lymphocyte function in myasthenia gravis. Neurology (Minneap.), 23, 1078-1083.

Behan, P. O., Simpson, J. A., and Heather, D. (1973). Immune response genes in myasthenia gravis. Lancet, 2 , 1033.

Bodmer, W. F. (1972.) Population genetics of the HL-A system: Retrospect and prospect. Histocompatibility Testing 1972, pp. 611-617. Edited by J. Dausset, and J. Colombani. Munksgaard: Copenhagen.

Bodmer, W. F., and Payne, R. (1965). Theoretical consideration of leucocyte grouping using multispecific sera. Histocompatibility Testing 1965, pp. 141-149. Edited by H. Balner, F. J. Cleton, and J. G. Eernisse. Munksgaard: Copenhagen. 
Ceppellini, R., and van Rood, J. J. (1974). The HL-A system. Genetics and molecular biology. Seminars in Hematology, 11, 233-251.

Dick, H. M., Behan, P. O., Simpson, J. A., and Durward, W. F. (1974). The inheritance of HL-A antigens in myasthenia gravis. Journal of Immunogenetics, 1, 401-412.

Feltkamp, T. E. W., van der Berg-Loonen, P. M., Nijenhuis, L. E., Engelfriet, C. P., van Rossum, A. L., van Loghem, J. J., and Oosterhuis, H. J. G. H. (1974). Myasthenia gravis, autoantibodies and HL-A antigens. British Medical Journal, 1, 131-133.

Fritze, D., Herrman, C. Jr, Faramarz, N., Smith, G. S., and Walford, R. L. (1974). HL-A antigens in myasthenia gravis. Lancet, 1, 240-243.

Gebhard, R. L., Katz, S. J., Marks, J., Shusters, S., Trapani, R. J., Rodentine, G. N., and Strober, W. (1973). HL-A antigen type and small intestinal disease in dermatitis herpetiformis. Lancet, 2, 760-762.

Grumet, F. C., Coukell, A., Bodmer, J. G., Bodmer, W. F., and McDevitt, H. O. (1971). Histocompatibility (HL-A) antigens associated with systemic lupus erythematosus. (A possible genetic predisposition to disease). New England Journal of Medicine, 285, 193-196.

Grumet, F. C., Konishi, J., Payne, R., and Kriss, J. P. (1973). Association of Graves disease with HL-A8. Clinical Research, 21, 493.

Kaakinen, A., Pirskanen, R., and Tiilikainen, A. (1975). LD antigens associated with HL-A8 and myasthenia gravis. Tissue Antigens. (In press.)

Kott, E., Genkins, G., and Rule, A. (1973). Leucocyte response to muscle antigens in myasthenia gravis. Relationship to clinical severity and presence of circulating antibodies. Neurology (Minneap.), 23, 374-380.

Kurland, L. T., and Alter, M. (1961). Current status of the epidemiology and genetics of myasthenia gravis. Myasthenia Gravis, pp. 307-336. Edited by H. R. Viets. Thomas: Springfield, Ill.

McDevitt, H. O., and Bodmer, W. F. (1974). HL-A, immune-response genes, and disease. Lancet, 1, 1269-1275.

MacKay, I. R., and Morris, P. J. (1972). Association of autoimmune active chronic hepatitis with HL-A1, 8. Lancet, 2, 793-795.

Namba, T., Arimori, S., and Grob, D. (1969a). Lymphocytes of patients with myasthenia gravis. Local effects in rats following intramuscular administration. Archives of Neurology, 21, 285-295.

Namba, T., Arimori, S., and Grob, D. (1969b). Effect on mice of intravenous administration of lymphocytes from normal subjects and from patients with myastenia gravis. Neurology (Minneap.), 19, 461-468.

Namba, T., Brunner, N. G., Brown, S. B., Mugurama, M., and Grob, D. (1971). Familial myasthenia gravis. Report of 27 patients in 12 families and review of 164 patients in 73 families. Archives of Neurology, 25, 49-60.
Nastuk, W. L., Strauss, A. J. L., and Osserman, K. E. (1959), Search for a neuromuscular blocking agent in the blood of patients with myasthenia gravis. American Journal of Medicine, 26, 394-409.

Nerup, J., Platz, P., Anderson, O. O., Christy, M., Lyngsøe, J., Poulsen, J. E., Ryder, L. P., Thomsen, M., Staub Nielsen, L., and Svejgaard, A. (1974). HL-A antigens and diabetes mellitus. Lancet, 2, 864-866.

Oosterhuis, H. J. G. H. (1964). Studies in myasthenia gravis. Part 1. A clinical study of 180 patients. Journal of Neurological Sciences, 1, 512-546.

Oosterhuis, H. J. G. H., and de Haas, W. N. D. (1968). Rheumatic diseases in patients with myasthenia gravis: an epidemiological and clinical investigation. Acta Neurologica Scandinavica, 44, 219-227.

Pirskanen, R., Tiilikainen, A., and Hokkanen, E. (1972). Histocompatibility (HL-A) antigens associated with myasthenia gravis. A preliminary report. Annals of Clinical Research, 4, 304-306.

Platz, P., Ryder, L., Staub Nielsen, L., Svejgaard, A., Thomsen, M., Christy, M., and Nerup, J. (1974). HL-A and idiopathic Addison's disease. Lancet, 2, 289.

Säfwenberg, J., Lindblom, J. B., and Osterman, P. O. (1973). HL-A frequencies in patients with myasthenia gravis. Tissue Antigens, 3, 465-469.

Simpson, J. A. (1960). Myasthenia gravis: a new hypothesis. Scottish Medical Journal, 5, 419-436.

Stokes, P. L., Asquith, P., Holmes, G. K. T., Macintosh, P., and Cooke, W. T. (1972). Histocompatibility antigens associated with adult coeliac disease. Lancet, 2, 162-164.

Strauss, A. J. L., Seegal, B. C., Hsu, K. C., Burkholder, P. M., Nastuk, W. L., and Osserman, K. E. (1960). Immunofluorescence demonstration of a muscle binding, complement-fixing serum globulin fraction in myasthenia gravis. Proceedings of the Society of Experimental Biology and Medicine, 105, 184-191.

Thorsby, E., Engeset, A., and Lie, S. O. (1971). HL-A antigens and susceptibility to diseases. A study of patients with acute lymphoblastic leukaemia, Hodgkin's disease, and childhood asthma. Tissue Antigens, 1, 147-152.

Tiilikainen, A., Eriksson, A. W., MacQueen, M. J., and Amos, D. B. (1972). The HL-A system in the Skolt Lapp population. Histocompatibility Testing 1972, pp. 85-92. Edited by J. Dausset and J. Colombani. Munksgaard: Copenhagen.

Vejjajiva, A., Vejjajiva, S., Amnueilaph, R., and Strisastra, P. (1974). Leucocyte response to thymic antigen in myasthenia gravis. Excerpta Medica International Congress Series, no. 334 , p. 71.

Whittingham, S., MacKay, I. R., and Kiss, Z. S. (1970). An interplay of genetic and environmental factors in familial hepatitis and myasthenia gravis. Gut, 11, 811-816. 